\title{
Derivation And Inflection Word Formation Used In Al Jazeera News
}

\author{
Ismah Nurngaini $^{1}$, Dwi Puji Hastuti ${ }^{2}$, Ria Andriani ${ }^{3}$ \\ ${ }^{1}$ Universitas Bina Sarana Informatika \\ e-mail: ismahnurngaini@gmail.com \\ ${ }^{2}$ Universitas Bina Sarana Informatika \\ e-mail: dwi.dsu@bsi.ac.id \\ ${ }^{3}$ Universitas Bina Sarana Informatika \\ e-mail: ria.rii@bsi.ac.id
}

\begin{abstract}
Cara Sitasi: Nurngaini, I., Hastuti, D. P., \& Andriani, R. (2019). Derivation And Inflection Word Formation Used In Al Jazeera News. Wanastra, 11(2), 151-158.
\end{abstract}

\begin{abstract}
New word formation cannot be avoided in making sentences, paragraphs, and also to speak, because words are part of the language which develops interaction between individuals in a society as human communication. The nature of communication are verbal communication (oral and writing) and non verbal communication (sign language and symbols). People often use media in verbal communication, such as written media or mass media (newspaper, magazines, billboards, tabloids and banners). This research analyzed about the structure of words contained in the article Al Jazeera News entitled "Syria's Refuge Children: Future lost to the war" which uses derivation and inflection word formation process. This research aims to know how word formation occurs and identifies how many new words are formed by derivation and inflection processes. Descriptive qualitative method uses in this research. It begins by reading theories of word formation which related to journal and books, determine the article, furthermore classifies the words that contain derivation and inflection process. From the both word formation process that used (derivation and inflection) in analyzing the article, the result of the study found inflection is mostly used, because in the article required grammatical function that contained in inflection.
\end{abstract}

Keywords: Derivation, Inflection, Word formation process

\section{INTRODUCTION}

Language as defined is an exclusively human property. Human and language is inseparable unity. As a social beings, human need language for communication. According to (Hartati, 2017:1), "Language is a sound system used by members of communities to work together, interact, and identity". By using language, people will be able to express their ideas, emotions, and desires.

Communication by means of language may be referred to as linguistic communication. Communication require using a language that contain linguistic. An individual who is not adequately exposed to linguistic input will not spontaneously develop language. Although every normal human is born with the capacity to acquire language, considerable external input is necessary to activate and utilize this capacity.

According to (Oktavia, 2017:2), "Word formation consist of a process in create new word where it was a result modification of old word". Word is part of language which has important role in forming a language. People use the word to make a sentence, but people sometimes do not know where the words come from and people do not know how the word is formed. For the example, many words are used in Newspaper either formal or informal. The use of appropriate words in the Newspaper is required.

Newspaper, it uses as an important part of our life. This not looking that much important after digital evolution but people who know its importance still buying and reading. Nowadays E-Newspaper, Electric Newspaper, is replacing printed version and the biggest benefit for people who are read newspapers on tablets, computer and mobile. Sometimes newspaper editor uses a complicated word formation that makes reader hard to understand. Usually English words used in newspaper are not single word. There are combination with other English words.

The writer choose the title Derivation and inflection word formation used in Al Jazeera News entitled "Syria's refugee children: futures lost to the war" by Barbara Bibbo aims to classify and analyze word formation process that used. A special focus will be 
two of ten word formation process, there are derivations and inflections.

Study of morpheme is a major way to investigate words, their internal structure, and how they are formed. Morpheme is important component in word formation. According to (Rustamaji, 2015:16), "Morphology cannot be separated to a linguistic terms for the most element unit of grammatical form. This element unit is called morpheme". Similiarly, according to (Kusumawardhani, 2015:3), "Morphology is the study of morphemes, which are the smallest significant units of grammar". It means morpheme is smallest part of language that can not be divided into smaller meaningful parts. One of the functions units grammatical used to indicate past tense. For example the word reopened consist of three morphemes. One minimal unit of meaning is open, another minimal of meaning is re-meaning again, and a minimal unit grammatical function is $e d$ indicating past tense.

Grammatical function of a morpheme is important , the meaning must be constant. Considering the English word lovely and Especially, end with suffix $-l y$. Although used the same suffix, when add $-l y$ to the adjective especial, that change into adverb. When add -ly to the noun love, that create an adjective. The conclusion, not all of the word ending with $-l y$ changes to be adverb. What on the suface appears to be a single morpheme turns out to be two. One attaches to adjective (especial) and create adverb, the other attaches to noun (love) and create adjective.

According to (Mu'tasim, 2014:6), "Morpheme is the meaningful unit that are used to form words". It means, morpheme is part of word, and can not be divided again produce a meaningful unit because word is the smallest part of a sentence.

Free morpheme according to (Yule, 2010:68), "Morphemes that can stand by themselves as single words, for example open and tour". It means free morpheme can stand alone which can potentially create word formation from basic word and have a meaningfully. While bound morpheme according to (Yule, 2010:68), "Forms that cannot normally stand alone and typically attached to another form, example as re-, - ist, -ed, -s. These forms are called affixes. Affixes consist of two kinds, namely prefixes and suffixes. In English, all affixes are bound morphemes". It means bound morpheme is depending of free morpheme.

\section{Word formation processes}

Theory of word formation included in morphology, the branch of linguistic which deals with studying word form and also word formation process. According to (Rustamaji, 2015:19), "Word formation is referred to all processes connected with changing the form of the word". It means to changing the word to the other word, that makes a new form or new meaning needed the process that is word formation.

Meanwhile, according to (Oktavia, 2017:2), "Word formation is dealing with the formation of words". In addition, according (Oktavia, 2017:2), "Word formation consist of a process in create new word where it was a result of modification of old word". From the definition, word formation processes is technic or way of creating new words and the new uses of the old words.

\section{Derivation}

(Rahmawati, 2012:10) stated, "Derivation morpheme makes explicit the word class assignment of the word to make it into an adjective, and adverb, or another part of speech". It means derivation morpheme changes the meaning of word through changing the class of word. Example Marry to Married, the base word is verb changes into adjective by adding -ed.

Whereas, According to (O'Grady, 1997:122), "Derivation forms a word with a meaning and/or category distinct from that of verb base through the addition of an affix". It means derivation is a process of word formation by adding affixes.

According to (Yule, 2010:59), "Affixes have to be added to the beginning of the word (e.g. un-, mis-). These are called prefixes. Other affixes have to be added to the end of the word (e.g. -less, ish) and are called suffixes". It means Affixation divided into two forms, they are prefixes and suffixes. Prefixes are affixes placed before the base word, and Suffixes are affixes placed after the base word.

\section{Inflection}

Language studies about singular and plural, past, present, and future. According to (O'Grady, 1997:135), "Inflection is the modification of a words form (through affixation, internal change, reduplication or suppletion) to indicate the grammatical subclass to which it belongs". It means inflection marked the contrast of grammatical subclass such as number (singular,plural), person (first, second, third), tense (past, present, future).

In the some word may be derivation and inflection will be found in the same word. (Katamba, 2005:47) stated, "When both inflectional and derivational morphemes are present, the inflectional morphemes are on the outer fringes of the word. Example:

Inflection of stems with derivational suffixes De-regul-at(e)-ed( *de-regul-ed-ate) Perfect-ion-ist- 
$s($ *Perfect- $s$-ion-ist)

In other words, derivation can create the input to inflection. A new lexeme that has been yielded by derivation can subsequently undergo inflection in order to ensure that the word has appropriate grammatical properties for the syntactic position in which it occurs". It means derivation attached first while inflection is added later, that is why they are presented in the same word, because from derivation can make inflection present in the word.

\section{RESEARCH METHODOLOGY}

Methodology used in this research was descriptive qualitative method. According to (Masruhah, 2015:37), "The methods of qualitative research are step that used to collect data by researcher usually use interview, observation, questionnaire, test and documentation". The writer collects some data from Al Jazeera News and search for some informations from books and internet to help in analyzing process.

The analysis of this research was started from reading and comprehending the theories of English word formation from the journal articles and theoretical books. The next step is reading $\mathrm{Al}$ Jazeera News to determine the article to be analyzed. Furthermore, identifying and classifying words which contain inflection and derivation, breaking them into their smaller units in order to find out the process within the word, and also double check the new meaning using dictionary. After the relevant data are obtained, inventorying them into observation table to conclude which word formation that mostly used in article which have been analyzed from Al Jazeera News.

\section{RESULTS AND DISCUSSION}

There are 120 words formation which consist of two types of English word formation process (Derivation and Inflection) used in article which have been analyzed from Al Jazeera News.

For derivation analysis, there are 5 words that formed by derivation prefixes, they are: (1) 1 prefix Em-, (2) 1 prefix Re-, (2) 1 prefix Im-, (3) 2 prefix Un-. Furthermore, there are 42 words consist of derivation suffixes, they are: (1) 1 suffix - an, (2) 8 suffix -ing, (3) 1 suffix -ist, (4) 1 suffix -ee, (5) 4 suffix -ion, (6) 8 suffix -ed, (7) 1 suffix -ive, (8) 8 suffix -ly, (9) 1 suffix -ment, (10) 3 suffix -ty, (11) 1 suffix -y, (12) 3 suffix -ation, (13) 1 suffix -ity, (14) 1 suffix -ence (15) 1 suffix -less.

For inflection analysis, there are 63 words, used 5 inflection suffixes, they are: (1) 32 noun plural marker (-s), (2) 18 past tense (-ed), (3) 4 present tense (-s), (4) 8 progressive aspect (-ing), (5) 1 superlative adjective (-est). The last is derivation and inflection analysis in one word. There are 10 words that formed with derivation and inflection analysis.

After doing analysis, the base form of word by the word formation process used derivation or inflection could be known. Mostly used in article is inflection word formation, it is because in writing or speaking needed grammatical function, which is included in inflection.

\section{Derivation Analysis}

Derivation is divided into two categories, which is prefixes and suffixes. There were some derivational prefixes found in the article:

Table 3.1. Derivation Prefixes Categories

\begin{tabular}{|c|c|c|c|}
\hline No & Word & $\begin{array}{l}\text { Base } \\
\text { Word }\end{array}$ & Explanation \\
\hline 1. & Empower & Power & $\begin{array}{l}\text { The base word is } \\
\text { noun changes into } \\
\text { verb by adding } \\
\text { Em- }\end{array}$ \\
\hline 2. & Rebuild & Build & $\begin{array}{l}\text { The word is still } \\
\text { verb, but by adding } \\
\text { Re- the meaning } \\
\text { has changes into } \\
\text { again }\end{array}$ \\
\hline 3. & Impossible & Possible & $\begin{array}{l}\text { The word is still } \\
\text { adjective, but by } \\
\text { adding Im- the } \\
\text { meaning has } \\
\text { changes to negative }\end{array}$ \\
\hline 4 & Unrealistic & Realistic & $\begin{array}{l}\text { The word is still } \\
\text { adjective, but by } \\
\text { adding Un-the } \\
\text { meaning has } \\
\text { changes to negative }\end{array}$ \\
\hline
\end{tabular}

From data number one, it can be seen that the word Empower is derived from the word Em- + power. Empower belongs to verb, whereas power is a noun and it is added prefix Em- before the base word to form the new word Empower. It can be said that prefix Em- changes a noun into verb.

Data number two is a process derivation that only changes the meaning from the word Rebuild derived from $R e-+$ build because not all derivation processes changes the part of speech. Build and Rebuild belongs to verb, this process is called derivation because different category of both words. 
The base word added prefix that is $R e$ - changes the meaning into "again". That means prefix $R e$ - used with the meaning "again" to indicate repetition.

The word Impossible in data number three is adjective derived from an adjective possible. It is derived from prefix $\mathrm{Im}^{-}+$possible. That means prefix Im- of the word Impossible changes the meaning relating incapable of happening or incapable undertaken (negative meaning).

From data number two and three, the word Unrealistic is an adjective have same derivation process that is not changes the part of speech. The word Unrealistic derived from prefix $U n-+$ realistic (adjective). Prefix Un- same as prefix Im-, changes the meaning of word that is giving negative or opposite force.

Derivation prefixes categories 5 words found in the article that are: empower, rebuild, impossible, unrealistic, uncommon, but only formed from four prefixes. Prefix $E m$ - changes noun into verb, prefix $R e$ - indicate repetition and prefix $I m$ - and prefix $U n$ giving negative meaning.

There were some derivational suffixes found in the article:

Table 3.2. Derivation Suffixes Categories

\begin{tabular}{|c|c|c|c|}
\hline No & Word & Base Word & Explanation \\
\hline 1. & Syrian & Syria & $\begin{array}{l}\text { The base word } \\
\text { is noun changes } \\
\text { into adjective } \\
\text { by adding -an }\end{array}$ \\
\hline 2. & Dreaming & Dream & $\begin{array}{l}\text { The base word } \\
\text { is noun changes } \\
\text { into verb by } \\
\text { adding -ing }\end{array}$ \\
\hline 3. & Journalist & Journal & $\begin{array}{l}\text { The word is } \\
\text { still noun, but } \\
\text { the meaning is } \\
\text { changes from } \\
\text { goods to a } \\
\text { person by } \\
\text { adding -ist }\end{array}$ \\
\hline 4. & Refugee & Refuge & $\begin{array}{l}\text { The word is } \\
\text { still noun, but } \\
\text { the meaning is } \\
\text { changes from } \\
\text { place to a } \\
\text { person by } \\
\text { adding -ee }\end{array}$ \\
\hline 5. & Education & Educate & $\begin{array}{l}\text { The base word } \\
\text { is verb changes } \\
\text { into noun by } \\
\text { adding -ion }\end{array}$ \\
\hline
\end{tabular}

\begin{tabular}{|c|c|c|c|}
\hline 6. & Married & Marry & $\begin{array}{l}\text { The base word } \\
\text { is verb changes } \\
\text { into adjective } \\
\text { by adding -ed }\end{array}$ \\
\hline 7. & Inquisitive & Inquisition & $\begin{array}{l}\text { The base word } \\
\text { is noun changes } \\
\text { into adjective } \\
\text { by adding -ive }\end{array}$ \\
\hline 8. & Abruptly & Abrupt & $\begin{array}{l}\text { The base word } \\
\text { is adjective } \\
\text { changes into } \\
\text { adverb by } \\
\text { adding -ly }\end{array}$ \\
\hline 9. & $\begin{array}{l}\text { Improvemen } \\
\mathrm{t}\end{array}$ & Improve & $\begin{array}{l}\text { The base word } \\
\text { is verb changes } \\
\text { into noun by } \\
\text { adding -ment }\end{array}$ \\
\hline 10. & Opportunity & Opportune & $\begin{array}{l}\text { The base word } \\
\text { is adjective } \\
\text { changes into } \\
\text { noun by adding } \\
\text {-ty }\end{array}$ \\
\hline 11. & Bloody & Blood & $\begin{array}{l}\text { The base word } \\
\text { is noun changes } \\
\text { into adjective } \\
\text { by adding -y }\end{array}$ \\
\hline 12. & $\begin{array}{l}\text { Document } \\
\text { ation }\end{array}$ & Document & $\begin{array}{l}\text { The base word } \\
\text { is verb changes } \\
\text { into noun by } \\
\text { adding -ation }\end{array}$ \\
\hline 13. & Relentlessly & Relent & $\begin{array}{l}\text { The base word } \\
\text { is verb changes } \\
\text { into adjective } \\
\text { by adding -less } \\
\text { and changes } \\
\text { into adverb by } \\
\text { adding -ly }\end{array}$ \\
\hline 14. & Electricity & Electric & $\begin{array}{l}\text { The base word } \\
\text { is adjective } \\
\text { changes into } \\
\text { adverb by } \\
\text { adding -ity }\end{array}$ \\
\hline 15. & Influence & Influent & $\begin{array}{l}\text { The base word } \\
\text { is adjective } \\
\text { changes into } \\
\text { noun by adding } \\
\text {-ence }\end{array}$ \\
\hline
\end{tabular}

Data number one is a sample that derivation changes noun Syria into adjective Syrian derived from the word Syria $+-a n$. The suffix -an that shapes a noun into adjective. In the article, suffix -an only found in one word that is Syrian. 
Data number two, the word dreaming derived from the word dream + -ing. Dreaming belongs to verb, whereas dream is noun and it is followed by the suffix - ing to form the new word dreaming. In other hand, the suffix -ing can formed verb into adjective (live into living) and verb into noun (make into making). The suffix - ing in the article found in eight words, that are dreaming, living, according, making, neighbouring, calling, running, fighting.

From data number three, it can be seen that the word journalist is derived from the word word journal + ist. As I mentioned before not all derivation processes changes the part of speech. In this case, the word journalist is noun derived from a noun journal. That means -ist is a suffix of noun, but changes the meaning goods to a person. One word only in the article used the suffix -ist.

The word refugee in data number four same from data number four before, derivation process not changes the part of speech but changes the meaning only. It is derived from the word refuge $+-e e$. The word refugee is noun derived from a noun refuge. That means suffix -ee changes the meaning from place to a person. In the article one word only used the suffix $-e e$.

Data number five is a sample that derivation changes verb educate into noun education, derived from the word educate + -ion. The suffix -ion that shapes a verb into a noun. In the article, four words used suffix -ion there are education, determination, generation, protection.

From data number six, it can be seen that the word married is derived from the word marry $+-e d$. Married belongs to adjective, whereas marry is verb and it is followed by the suffix -ed to form the new word married. There are seven words in the article used suffix -ed as derivation process: married, educated, protacted, displaced, wounded, registered, recruited.

The word inquisitive in data number seven, shows a derivation process of suffix -ive that changes noun inquisition into adjective insquitive. This process can be drawn as inquisition $+-i v e$. The suffix -ive in the article used only in one word.

Data number eight, the word abruptly that is adverb derived from the word abrupt $+-l y$. Suffix $-l y$ in derivation process changes adjective abrupt into adverb abruptly. Eight words in the article used the suffix $-l y$ : abruptly, internally, apparently, especially, serously, nearly, relentlessly.

The word impovement in data number nine is derived from the word improve $+\quad$-ment. The suffix -ment changes the word from verb improve into noun improvement. In the article, the suffix -ment only used in the one word.

From data number ten, it can be seen that the word opportunity is derived from the word opportune + ty. Opportunity belongs to noun, whereas opportune is adjective and it is followed by the suffix $-t y$ to form the new word. There are three words in the article that used the suffix -ty : opportunity, proverty, electricity.

Data number eleven, the word bloody is derived from the word blood $+-y$. Bloody is a noun followed by the suffix $-y$ changes into adjective. The suffix $-y$ in the article used only in one word.

The word documentation in data number twelve is derived from the word document + -ation. Documentation belongs to noun, whereas document is verb, by the suffix -ation followed the word that can changes into the new word. Three words in the article used the suffix -ation that are: documentation, starvation, exploitation.

From data number thirteen, the word relentlessly is derived from the word relent + -less $+-l y$. Relentlessly can be form because followed by two suffix that are suffix -less and than suffix -ly. Relentlessly belongs to adverb, whereas relent is verb, by adding suffix -less the word changes into adjective, and then followed the suffix -ly changes into adverb. In the article, the word that used two suffix in one word only relentlessly.

Data number fourteen, it can be seen the word electricity derived from the word electric $+-i t y$. The word electricity is noun, whereas electric is adjective and it is followed by the suffix -ity to form the new word electricity. The suffix -ity in the article used only in one word that is electricity.

The word Influence in data number seventeen derived from the word influent + -ence. The suffix ence changes an adjective influent into a noun influence. In the article, suffix -ence only used in one word that is influnce.

From data of analysis, 42 words have been found in article that use only 16 suffixes.

\section{Inflection Analysis}

There are 63 words which is formed by inflection suffixes, 5 Inflection suffixes that used in the article: noun plural marker (-s), past tense (-ed), present tense (-s), progressive aspect (-ing), superlative adjective (-est).

Table 3.3. Inflection Suffixes Categories 


\begin{tabular}{|c|c|c|c|}
\hline No & Word & $\begin{array}{l}\text { Base } \\
\text { Word }\end{array}$ & Explanation \\
\hline 1. & Years & Year & $\begin{array}{l}\text { The base word is } \\
\text { year added }-\mathrm{s} \text {, it } \\
\text { shows noun plural }\end{array}$ \\
\hline 2. & Forced & Force & $\begin{array}{l}\text { The base word is } \\
\text { force added -ed, it } \\
\text { shows the event } \\
\text { happen in the past } \\
\text { (past } \\
\text { tense) }\end{array}$ \\
\hline 3. & Steps & Step & $\begin{array}{l}\text {-s it shows present } \\
\text { tense verb, the } \\
\text { activity is done in } \\
\text { present }\end{array}$ \\
\hline 4. & Including & Include & $\begin{array}{l}\text { The base word is } \\
\text { include added -ing, } \\
\text { it shows that } \\
\text { activity is on going }\end{array}$ \\
\hline 5. & Youngest & Young & $\begin{array}{l}\text { The base word is } \\
\text { young added - est, } \\
\text { it shows superlative } \\
\text { adjective }\end{array}$ \\
\hline
\end{tabular}

From data sample number 1 , the suffix $-\mathrm{s}$ in the word years is indicating of plural marker. The suffix -s can be said as inflection because does not change the category and part of speech. In the article there are 32 words that used the suffix $-\mathrm{s}$ : years, schoolmates, brides, books, steps, jeans, ones, girls, agencies, means, families; countries, refugees, camps, communities, needs, prospects, remains, parties, months, reports, casualties, injuries, deaths, times, daughters, brides, parents, kids, tents, camps, events.

Another type of suffix indicating the process of inflection is suffix -ed in the word forced which indicates the past form of the verb force. Suffix -ed used in 18 words in the articel that are: forced, spearheaded, dropped, needed, conducted, received, killed, verified, abused, started, campaigned, hated, looked, scorned, seemed, supported, called, witnessed.

Another inflectional suffix is found in the sample number 3 . The sufiix $-s$ in the data number 3 , is different case from data number 1 . The suffix $-s$ in data number 1 is plural marker, wether the suffix $-s$ in the data number 3 (steps) indcates that the word is present tense verb. In the article 4 words used the suffix $-s$ it is shows present tense verb, that are : shows, steps, matters, sides.

The suffix -ing in the word including, indicates progressive aspect it shows that activity is on going. In the article 8 words that used suffix -ing : struggling, including, providing, returning, going, visiting.waiting, failing.

From data number 5, the suffix -est in the word youngest indicate superlative adjective. Therefore, the word young, younger, and youngest are representations of the same lexeme young. Only the one word that is youngest used suffix -est in the article.

\section{Derivation and Inflection Analysis}

In the article, there are 10 words that formed with derivation and inflection in one word:

Table 3.4. Derivation and Inflection Form Categories

\begin{tabular}{|c|c|c|c|}
\hline No & Word & $\begin{array}{c}\text { Base } \\
\text { Word }\end{array}$ & Explanation \\
\hline 1. & Encircled & Circle & $\begin{array}{l}\text { The base word is } \\
\text { added with En- } \\
\text { which is included } \\
\text { derivation (prefix) } \\
\text { and also added } \\
\text { with -ed that } \\
\text { shows inflection } \\
\text { (past tense) }\end{array}$ \\
\hline 2. & Represents & Present & $\begin{array}{l}\text { The base word is } \\
\text { added with Re- } \\
\text { which is included } \\
\text { derivation (prefix) } \\
\text { and also added } \\
\text { with -s that shows } \\
\text { inflection } \\
\text { (activity is done in } \\
\text { present tense) }\end{array}$ \\
\hline 3. & Displaced & Place & $\begin{array}{l}\text { The base word is } \\
\text { added with Dis- } \\
\text { which is included } \\
\text { derivation (prefix) } \\
\text { that means } \\
\text { negative word } \\
\text { indicating } \\
\text { removal and also } \\
\text { added with -ed } \\
\text { that shows } \\
\text { inflection (past } \\
\text { tense) }\end{array}$ \\
\hline 4. & Beloved & Love & $\begin{array}{l}\text { The base word is } \\
\text { added with Be- } \\
\text { which is included } \\
\text { derivation (prefix) } \\
\text { and also added } \\
\text { with -ed that } \\
\text { shows inflection } \\
\text { (past tense) }\end{array}$ \\
\hline
\end{tabular}




\begin{tabular}{ll}
\hline 5. Becomes Come & The base word is \\
& added with Be- \\
& which is include \\
& derivation (prefix) \\
& and also added \\
& with $-\mathrm{s}$ that shows \\
& inflection (activity \\
& is done in present)
\end{tabular}

\begin{tabular}{|c|c|c|c|}
\hline 6. & Recalled & Call & $\begin{array}{l}\text { The base word is } \\
\text { added with Re- } \\
\text { which is included } \\
\text { derivation (prefix) } \\
\text { and also added } \\
\text { with -ed that } \\
\text { shows inflection } \\
\text { (past tense) }\end{array}$ \\
\hline 7. & $\begin{array}{l}\text { Unaccompa } \\
\text { nied }\end{array}$ & $\begin{array}{l}\text { Accomp } \\
\text { any }\end{array}$ & $\begin{array}{l}\text { The base word is } \\
\text { verb changes into } \\
\text { adjective } \\
\text { adding by } \\
\text { derivation (prefix) } \\
\text { and also added } \\
\text { with -ed that } \\
\text { shows inflection } \\
\text { (past tense) }\end{array}$ \\
\hline
\end{tabular}

8. Encouraging Courage The base word is added with Enwhich is included derivation (prefix) and also added with -ing that shows inflection (activity is on going)

9. Encouragem Courage The base word is ent added with Enwhich is included derivation (prefix) and also added with -ment that shows inflection (noun)

10. Especially Special The base word added with Ewhich is included derivation (prefix) and also added with-ly that shows inflection (adverb)

\section{CONCLUSION}

After analyzing the article of $\mathrm{Al}$ Jazeera News, derivation affixation produces new word with different meaning from the base word since the addition of suffixes or prefixes helps to form a new word, and sometimes new class of word. For example, suffixes of "Journal" into "Journalist". Journal is the base word that is noun, when adding suffixes -ist not changes the class of word, but the meaning changes from goods to a person.

Different from derivation, inflection is the process of forming word by adding affixes that only has additional suffixes. Inflection is the formation of word by adding affixes without changing the word class or the meaning of the base word but marked grammatical function. For example, "Book" that means a single book, when added -s into "Books" it shows plural book. However, both "Book" and "Books" are both still as noun.

Mostly used in the article which have been analyzed from Al Jazeera News with two word formation processes (derivation and inflection) is inflection, it is because writing or speaking needed grammatical function, which is included in inflection.

By analyzing of word formation, the writer knows how words are formed to the new words with new meaning, with different class of word (derivation) or the new word marked grammatical function (inflection). As the result the word formation process, easier to make a sentence with the new words from the base words, facilitate the reader to understand the new meaning of the new word which carried by a word formation.

\section{BIBLIOGRAPHY}

Bauer, L. (2007). The Linguistics Student's Handbook. EDINBURGH UNIVERSITY PRESS.

Fagan, S. M. B. (2009). A Linguistic Introduction (First). New York: United States of America by Cambridge University Press.

Hartati. (2017). CODE-MIXING IN SONG LYRIC $B Y A F G A N$. Jakarta.

Katamba, F. (2005). English Words. New York: Taylor \& Francis e-Library.

Kusumawardhani, P. (2015). THE ANALYSIS OF MORPHOLOGY IN WRITING AN ENGLISH NARRATIVE COMPOSITION, $\operatorname{VII}(1), 2$.

Kusumawardhani, P. (2018). THE ERROR

ANALYSIS OF DERIVATIONAL MORPHOLOGY IN EFL' S ENGLISH NARRATIVE COMPOSITION, 2(1), 2. 
https://doi.org/10.26858/ijole.v2i1.4857

Masruhah, E. (2015). THE ANALYSIS OF ILLOCUTIONARY ACTS IN " BRAVE "MOVIE. Salatiga.

Mu'tasim, A. (2014). BOUND MORPHEME IN ARTICLES OF "JAKARTA POST" NEWSPAPER. Jakarta.

Nuraeni, C. (2018). Word Formation Used In J + Newspaper, $X(1), 1$.

O’Grady, W. (1997). Contemporary Linguistics (3rd ed.). New York: St Martins Press.

Oktavia, F. (2017). AN ANALYSIS OF WORD FORMATION PROCESSES OF SLANG WORDS IN "THE BEGINNING" ALBUM BY BLACK EYED PEAS, 2.

Rahmadini, R. (2017). COMPOUND WORDS OF WORD FORMATION PROCESS IN NOVEL SONS AND LOVERS LEVEL 5 BY LAWRENCE, 1.

Rahmawati, A. (2012). WORD FORMATION PROCESSES ON SLANG WORDS USED BY TRANSSEXUAL. Diponegoro University, Semarang.
Rustamaji, E. (2015). PROCESS OF ENGLISH WORD FORMATION FOUND IN ADVERTISEMENT BOARDS IN KENDAL REGENCY FACULTY OF LANGUAGES AND ARTS. Semarang.

Yule, G. (2010). The Study of Language (Fourth). New York: Cambridge University Press.

\section{PROFIL PENULIS}

Ismah Nurngaini, A.Md lahir di Banjarnegara. Telah mendapatkan gelar Ahli Madya Bahasa Inggris di Akademi Bina Sarana Informatika dengan program studi Bahasa Inggris.

Dwi Puji Hastuti, S.S lahir di Jakarta. Bergabung dengan Akademi Bahasa Asing sejak 2015. Telah mendapatkan gelar Sarjana Sastra di Sekolah Tinggi Ilmu Bahasa Asing dengan program studi sastra inggris dan saat ini sedang melanjutkan studi S2 di Universitas Indraprasta PGRI Jakarta.

Ria Andriani, S.M lahir di Padang. Bergabung dengan Akademi Sekertari dan Manajemen sejak 2015. Telah mendapatkan gelar Sarjana Manajemen di Institut Bisnis dan Informatika Kosgoro dengan program studi manajemen dan saat ini sedang melanjutkan studi S2 di Universitas Budi Luhur Jakarta. 